Archives of Sexual Behavior, Vol. 35. No.3, June 2006, pp. 263-278.

\title{
Clinical and Theoretical Parallels Between Desire for Limb Amputation and Gender Identity Disorder
}

\author{
Anne A. Lawrence, M.D., Ph.D. ${ }^{2}$
}

Received May 11, 2005; revision received October 20, 2005; accepted November 5, 2005. Published online: 24 June 2006

Desire for amputation of a healthy limb has usually been regarded as a paraphilia (apotemnophilia), but some researchers propose that it may be a disorder of identity, similar to Gender Identity Disorder or transsexualism. Similarities between the desire for limb amputation and nonhomosexual male-to-female $(\mathrm{MtF})$ transsexualism include profound dissatisfaction with embodiment, related paraphilias from which the conditions plausibly derive (apotemnophilia and autogynephilia), sexual arousal from simulation of the sought-after status (pretending to be an amputee and transvestism), attraction to persons with the same body type one wants to acquire, and an elevated prevalence of other paraphilic interests. K. Freund and R. Blanchard (1993) proposed that nonhomosexual MtF transsexualism represents an erotic target location error, in which men whose preferred erotic targets are women also eroticize their own feminized bodies. Desire for limb amputation may also reflect an erotic target location error, occurring in combination with an unusual erotic target preference for amputees. This model predicts that persons who desire limb amputation would almost always be attracted to amputees and would display an increased prevalence of gender identity problems, both of which have been observed. Persons who desire limb amputation and nonhomosexual MtF transsexuals often assert that their motives for wanting to change their bodies reflect issues of identity rather than sexuality, but because erotic/romantic orientations contribute significantly to identity, such distinctions may not be meaningful. Experience with nonhomosexual $\mathrm{MtF}$ transsexualism suggests possible directions for research and treatment for persons who desire limb amputation.

KEY WORDS: apotemnophilia, acrotomophilia, transsexualism, gender identity disorder, autogynephilia

\section{INTRODUCTION}

The desire for amputation of a healthy limb was first reported in 1785 by Sue (cited in Johnston \& Elliott, 2002), but, until recently, descriptions of this phenomenon were limited to a few case reports (Bensler \& Paauw, 2003; Berger, Lehrmann, Larson, Alverno, \& Tsao, 2005; Everaerd, 1983; Money, 1990; Money, Jobaris, \& Furth, 1977; Storm \& Weiss, 2003; Wakefield, Frank, \& Meyers, 1977). Persons who wanted to have healthy limbs amputated were

\footnotetext{
${ }^{1}$ Portions of this article were presented at the 3rd annual International Body Integrity Identity Disorder Conference, New York, New York, June 2003 and at the 30th annual meeting of the International Academy of Sex Research, Helsinki, Finland, June 2004.

${ }^{2} 1812$ E. Madison St., Suite 102, Seattle, Washington.

${ }^{3}$ To whom correspondence should be addressed at $1812 \mathrm{E}$. Madison St., Suite 102, Seattle, Washington 98122-2876; email: alawrence@mindspring.com
}

thought.to be extremely rare and, if not psychotic or delusional, were believed to have a paraphilia. Money et al. (1977) coined the term apotemnophilia to describe this paraphilia. The desire for limb amputation, expressed by nonpsychotic individuals, has recently gained wider attention as a result of amputations performed on two such persons by a Scottish surgeon in 1997 and 1999 (Dyer, 2000). Further attention has come from discussions of the phenomenon in magazine articles (Dotinga, 2000; Elliot, 2000; Horn, 2003), books (Elliott, 2003; Furth \& Smith, 2000), television documentaries (BBC2 Horizon, 2000), radio programs (Duncan, 2002), motion pictures (Gilbert, 2003), and Internet sites (Body Integrity Identity Disorder, n.d.).

A few professionals familiar with the phenomenon (e.g., First, 2005; Furth \& Smith, 2000; Smith, 2003) have proposed that, in some cases, the desire for limb amputation may be similar to transsexualism (American 
Psychiatric Association [APA], 1987; World Health Organization, 1992) or Gender Identity Disorder (GID; APA, 2000) and have proposed terms like Amputee Identity Disorder (Furth \& Smith, 2000) or Body Integrity Identity Disorder (First, 2005) as alternatives to apotemnophilia. In this article, I will describe the phenomenology of the desire for limb amputation, as this manifests in nonpsychotic, nondelusional persons; discuss the clinical and theoretical parallels between the desire for limb amputation and transsexualism/GID; and consider possible implications of these parallels for research and treatment. In the discussion that follows, the qualifier "nonpsychotic, nondelusional" should always be understood when I refer to "desire for limb amputation," "persons who desire limb amputation," etc.

\section{Amputation-Related Interests, Erotic Preferences, and Behaviors}

Persons who want to undergo limb amputation typically experience an intense desire or overwhelming compulsion to change their bodies to match their idealized images of themselves as amputees (First, 2005; Furth \& Smith, 2000). They usually describe their feelings as developing early in life, often before puberty (First, 2005). Persons who want to become amputees sometimes refer to themselves as wannabes (Bruno, 1997; Duncan, 2002) and their condition is sometimes called wannabeism. Although some persons who want to undergo limb amputation acknowledge that sexual arousal to the idea of being an amputee is one aspect of their desire (Elliott, 2003), most emphasize that they are primarily seeking a sense of wholeness or completeness or are attempting to correct a mismatch between their bodies and their identities (First, 2005; Furth \& Smith, 2000). Desire for limb amputation is often associated with two other unusual interests and behaviors related to amputation. These are (a) attraction to amputees as romantic or sexual partners and (b) experiencing sexual arousal or pleasure from pretending to be an amputee.

A preferential attraction to amputees as romantic or sexual partners was first described during the late 19th century in case reports by Reynolds (cited in Ellis, 1936) and Lydston (cited in Krafft-Ebing, 1903/1965). Attraction to amputees has been called amelotatism (Dixon, 1983; Nattress, 1996; Riddle, 1989) or acrotomophilia (Money, 1986). Persons who experience this attraction typically call themselves devotees (Bruno, 1997; Riddle, 1989) or amelotatists (Nattress, 1996). There are numerous case reports describing romantic or erotic attraction to amputees (Bruno, 1997; Everaerd, 1983; London \& Caprio, 1950; Massie \& Szajnberg, 1997; Money, 1986, 1990;
Money et al., 1977; Money \& Simcoe, 1986; Wakefield et al., 1977; Wise \& Kalyanam, 2000; Woody, 1973).

There are also several case reports of persons who experience sexual arousal (Bruno, 1997; London \& Caprio, 1950; Money, 1990; Money \& Simcoe, 1986; Wakefield et al., 1977; Woody, 1973) or satisfaction that is not explicitly sexual (Berger et al., 2005; Everaerd, 1983) from pretending to be amputees. These individuals may bind or conceal a limb or use assistive devices (crutches, wheelchairs, prosthetic limbs, etc.) in order to impersonate amputees. No special term has been coined to describe this phenomenon; in both professional and lay publications, it is simply called pretending, and its practitioners, pretenders (Bruno, 1997). Case reports suggest that pretending is virtually always accompanied by acrotomophilia (Bruno, 1997; Everaerd, 1983; London \& Caprio, 1950; Money, 1990; Money \& Simcoe, 1986; Wakefield et al., 1977; Woody, 1973) and sometimes by apotemnophilia (Berger et al., 2005; Everaerd, 1983; Money, 1990; Wakefield et al., 1977). Bruno (1997) proposed that acrotomophilia, pretending, and apotemnophilia may simply be different manifestations of the same underlying phenomenon.

Three large surveys have been conducted among persons with amputation-related interests. All three demonstrate substantial co-occurrence of devoteeism/acrotomophilia, pretending, and wannabeism/apotemnophilia. The earliest survey, a study of devotees, was conducted in 1976 by Ampix, a company that specialized in selling stories and photographs of amputees to interested persons. The Ampix survey and its results were summarized by Dixon (1983) and Riddle (1989). Ampix sent questionnaires to 315 persons on their mailing list, from whom they received 195 (62\%) completed questionnaires. Respondents included 190 heterosexual men, 4 homosexual men, and 1 bisexual woman, all of whom considered themselves devotees. Over $70 \%$ of respondents had fantasized being an amputee and 52\% had pretended to be an amputee, sometimes publicly. Although the questionnaire asked respondents, "Do you consciously desire to become an amputee?" (Riddle, p. 275), neither Riddle nor Dixon discussed participants' responses to this question.

A second survey of amelotatists/devotees was conducted by Nattress (1996), who recruited most participants at social gatherings for female amputees and male devotees. He collected data from 61 men, using three personality inventories and a questionnaire based on the Ampix survey. He excluded data from 11 men whose responses he considered invalid, resulting in 50 participants. Of these, roughly half reported that they had pretended to be an amputee and 22\% agreed that they "would like to be an amputee" (p. 134). 
Table I. Characteristics of Homosexual and Nonhomosexual MtF Transsexualism and Desire for Limb Amputation

\begin{tabular}{|c|c|c|c|}
\hline Characteristic & $\begin{array}{l}\text { Homosexual } \mathrm{MtF} \\
\text { transsexualism }\end{array}$ & $\begin{array}{l}\text { Nonhomosexual } \\
\mathrm{MtF} \text { transsexualism }\end{array}$ & $\begin{array}{l}\text { Desire for limb } \\
\text { amputation }\end{array}$ \\
\hline Profound discontent with embodiment and desire to surgically alter the body & Usually & Usually & Yes \\
\hline Simulation of the desired embodiment or status using clothing, prostheses, etc. & Yes $^{\mathrm{a}}$ & $\mathrm{Yes}^{\mathrm{a}}$ & Usually $^{\mathrm{b}}$ \\
\hline Natural resemblance to the desired embodiment or status provides rationale for surgery & Yes & No & No \\
\hline Closely related paraphilia from which the condition plausibly derives & No & $\mathrm{Yes}^{\mathrm{c}}$ & Yes $^{\mathrm{d}}$ \\
\hline Sexual arousal associated with simulation of the desired embodiment or status & Rarely & Usually & Usually? \\
\hline Sexual attraction to persons with the desired embodiment & No & Usually & Usually \\
\hline Elevated prevalence of other paraphilic interests & Unknown & Yes & Yes \\
\hline Belief that paraphilia-based explanations of the condition are inaccurate or incomplete & Not applicable & Often & Often \\
\hline
\end{tabular}

${ }^{\mathrm{a} C}$ Cross-dressing or transvestism.

${ }^{\mathrm{b}}$ Pretending to be an amputee.

cAutogynephilia.

${ }^{\mathrm{d}}$ Apotemnophilia.

Recently, First (2005) used semistructured telephone interviews to survey 52 persons who had expressed a wish to become an amputee or who had succeeded in doing so. About two thirds of participants were recruited from Internet discussion groups and about one third from referrals by other participants. Forty-seven $(90 \%)$ participants were male, $4(8 \%)$ were female, and 1 was intersexed and raised as a male; 32 $(62 \%)$ participants reported that they were heterosexual and the remainder reported that they were homosexual or bisexual. First (2005) noted that the high proportion of nonheterosexual participants was "partly explained by the fact that nine of the subjects were referred to the study by one subject who was himself homosexual, eight of whom were also homosexual" (p. 921). Nine (17\%) participants had undergone a major limb amputation. Forty-eight (92\%) participants had pretended to be an amputee and 45 (87\%) acknowledged sexual attraction to amputees. Fifteen (29\%) participants reported other paraphilic interests, including $8(15 \%)$ with transvestic fetishism. Ten (19\%) participants reported they had sometimes wished to be the opposite sex or felt that they were in the body of the wrong sex; of these, 7 (13\%) participants had crossed-dressed, not including the 8 participants who had cross-dressed in connection with transvestic fetishism. Six (12\%) participants had considered sex reassignment and 1 (2\%) had undergone sex reassignment.

\section{Parallels Between Male-to-Female Transsexualism and Desire for Limb Amputation}

Clinicians and researchers have frequently observed that there exist two distinct types or categories of male-to-female (MtF) transsexualism/GID (e.g., Blanchard, 1988, 1989a; Buhrich \& McConaghy, 1978; Cohen-Kettenis \& Gooren, 1999; Doorn, Poortinga, \& Verschoor, 1994;
Freund, Steiner, \& Chan, 1982; Money \& Gaskin, 1970-1971; Whitam, 1997). One category of MtF transsexualism includes persons who were overtly feminine as children, who are very feminine as adults, and who are exclusively sexually attracted to men; these individuals are usually referred to as homosexual $\mathrm{MtF}$ transsexuals (Cohen-Kettenis \& Gooren, 1999). The other category of MtF transsexualism includes persons who were not overtly feminine during childhood, who are not remarkably feminine as adults, and who are not exclusively sexually attracted to men, but who may be sexually attracted to women, to women and men, or to neither sex; these individuals are usually referred to as nonhomosexual $\mathrm{MtF}$ transsexuals (Cohen-Kettenis \& Gooren, 1999). Nearly all persons of this second MtF transsexual type have a history of transvestic fetishism or sexual arousal with cross-dressing (Blanchard, 1985; Blanchard, Clemmensen, \& Steiner, 1987). Both types of MtF transsexualism display parallels to the desire for limb amputation. I will argue, however, that for homosexual $\mathrm{MtF}$ transsexualism, the parallels are few and superficial, whereas, for nonhomosexual $\mathrm{MtF}$ transsexualism, the parallels are more numerous and more clinically and theoretically significant.

A few parallels exist between both types of $\mathrm{MtF}$ transsexualism/GID and the desire for limb amputation; two of these are displayed in the first two rows of Table I. In all three conditions, nearly all affected persons experience profound dissatisfaction with their bodies, which they desire to surgically modify to achieve a more acceptable embodiment. ${ }^{4}$ Based on a review of over 50 transsexual

\footnotetext{
${ }^{4}$ Most authorities believe that the sine qua non of adult transsexualism/GID is the desire to live as a member of the other sex, not the desire to surgically alter the body. For example, the International Statistical Classification of
} 
autobiographies, including many written by homosexual and nonhomosexual MtF transsexuals, Prosser (1998) concluded that persons with adult transsexualism/GID who seek sex reassignment "continue to deploy the image of wrong embodiment because being trapped in the wrong body is simply what transsexuality feels like" (p. 69). Participants in the survey by First (2005) used similar language to describe their motivations for seeking limb amputation, including the "wrong body" metaphor. Furth and Smith (2000) likewise stated that persons who want to become amputees "believe that they are living in the 'wrong body form'”, (p. 75).

Moreover, in both types of $\mathrm{MtF}$ transsexualism and in desire for limb amputation, individuals nearly always engage in simulation of their desired embodiment or status, using clothing, prostheses, etc. In the case of homosexual and nonhomosexual $\mathrm{MtF}$ transsexualism, this simulation is called cross-dressing, an activity that essentially all $\mathrm{MtF}$ transsexuals engage in. Cross-dressing consistently for at least one year is usually an eligibility requirement for sex reassignment surgery (SRS; Meyer et al., 2001). In the case of desire for limb amputation, simulation of the desired embodiment involves pretending to be an amputee; in the study by First (2005), 92\% of respondents said they had engaged in this behavior.

There are also several important parallels between nonhomosexual $\mathrm{MtF}$ transsexualism and desire for limb amputation that are not observed in homosexual $\mathrm{MtF}$ transsexualism. The first of these, displayed in the third row of Table I, involves a significant characteristic that is present in homosexual $\mathrm{MtF}$ transsexuals but that is conspicuously absent in nonhomosexual MtF transsexuals and in persons who desire limb amputation. Homosexual MtF transsexuals are usually very feminine in their appearance and behavior (Whitam, 1987, 1997; see also Blanchard, Dickey, \& Jones, 1995) and thus tend to naturally resemble persons with the embodiment or status they

Diseases and Related Health Problems (World Health Organization, 1992) describes transsexualism as

A desire to live and be accepted as a member of the opposite sex, usually [italics added] accompanied by a sense of discomfort with, or inappropriateness of, one's anatomic sex, and a wish to have surgery and hormonal treatment to make one's body as congruent as possible with one's preferred sex. (p. 365)

Similarly, the Diagnostic and Statistical Manual of Mental Disorders (APA, 2000) states that

Adults with Gender Identity Disorder are preoccupied with their wish to live as a member of the other sex. This preoccupation may be manifested as an intense desire to adopt the social role of the other sex or [italics added] to acquire the physical appearance of the other sex through hormonal or surgical manipulation. (p. 577) desire (i.e., women). This natural resemblance provides an obvious rationale for their pursuing SRS. A natural resemblance to the desired embodiment or status is not characteristic of nonhomosexual MtF transsexuals, who are typically not highly feminine in their appearance or behavior (Blanchard, 1990; Whitam, 1987; see also Blanchard et al., 1995), nor is it characteristic of persons who desire limb amputation, who do not naturally resemble, in any observable way, the condition or status of amputees (e.g., they do not have small, deformed, or nonfunctional limbs; First, 2005). As a result, nonhomosexual MtF transsexuals and persons who desire limb amputation appear to lack obvious rationales for wanting to change their bodies and statuses.

The remaining parallels between nonhomosexual $\mathrm{MtF}$ transsexualism and desire for limb amputation involve the presence of paraphilia-related characteristics that are absent, infrequent, or unreported in homosexual $\mathrm{MtF}$ transsexualism. These parallels are displayed in the last five rows of Table I.

Nonhomosexual MtF transsexualism and desire for limb amputation are each associated with a closely related paraphilia and may be a direct outgrowth of that paraphilia. Homosexual $\mathrm{MtF}$ transsexualism, in contrast, has not been associated with a specific paraphilia or theorized to be the outgrowth of a paraphilia. Blanchard (1989a) observed that nearly all nonhomosexual $\mathrm{MtF}$ transsexuals displayed a paraphilic sexual interest that he called autogynephilia, which he defined as "a male's propensity to be sexually aroused by the thought or image of himself as a female" (Blanchard, 1989b). He proposed that the desire for SRS of nonhomosexual MtF transsexuals was a direct outgrowth of their autogynephilia (Blanchard, 1991). A history of autogynephilic sexual arousal is very common in nonhomosexual $\mathrm{MtF}$ transsexuals who undergo SRS. Lawrence (2005) found that, among $199 \mathrm{MtF}$ transsexuals who were classified as nonhomosexual based on their sexual partner history before SRS, 178 (89\%) reported one or more episodes of autogynephilic sexual arousal, with median and modal frequencies of hundreds of episodes or more. Similarly, desire for limb amputation has usually been regarded as a reflection of apotemnophilia, a recognized paraphilia (Money et al., 1977). First (2005) observed that $72 \%$ of his male participants who desired limb amputation reported a history of sexual arousal to the idea of being an amputee. Moreover, $67 \%$ of First's participants stated that one "important reason" for seeking limb amputation was "in order to feel sexually excited" (p. 923). This demonstrates that the desire for limb amputation is often associated with paraphilic sexual arousal and may sometimes be motivated by this arousal. 
I will argue that the desire for limb amputation can be understood as a direct outgrowth of paraphilic sexual attraction to the idea of being an amputee.

In most cases of nonhomosexual $\mathrm{MtF}$ transsexualism, simulation of the desired embodiment or status by cross-dressing is, or once was, associated with sexual arousal. In many or most cases of desire for limb amputation, simulation of the desired embodiment or status by pretending also appears to be associated with sexual arousal, although the evidence is less definitive. Cross-dressing in homosexual $\mathrm{MtF}$ transsexualism, in contrast, is rarely, ${ }^{4}$ if ever, associated with sexual arousal (Whitam, 1997). About three quarters of nonhomosexual MtF transsexuals and nonhomosexual gender-dysphoric males report sexual arousal with crossdressing (Blanchard, 1985; Blanchard et al., 1987). Moreover, Blanchard, Racansky, and Steiner (1986) demonstrated that nonhomosexual gender-dysphoric males who did not acknowledge sexual arousal to cross-dressing displayed physiological evidence of arousal when listening to audiotapes of cross-dressing scenarios. Similarly, Lawrence (2005) reported that $89 \%$ of nonhomosexual $\mathrm{MtF}$ transsexuals gave a history of sexual arousal to cross-dressing or cross-gender fantasy. As previously noted, most case reports of pretending (e.g., Bruno, 1997; London \& Caprio, 1950; Money, 1990; Money \& Simcoe, 1986; Wakefield et al., 1977; Woody, 1973) describe associated sexual arousal. First (2005) apparently did not ask his participants whether

\footnotetext{
${ }^{5} \mathrm{~A}$ few studies have reported prevalence rates of sexual arousal with cross-dressing ranging from $10 \%$ to $36 \%$ in ostensibly homosexual $\mathrm{MtF}$ transsexuals and genderdysphoric males (Bentler, 1976; Blanchard, 1985; Blanchard, Clemmensen, \& Steiner, 1987; Freund et al., 1982; Leavitt \& Berger, 1990). It seems probable, however, that most of the ostensibly homosexual persons who reported sexual arousal with cross-dressing were not genuinely homosexual but were, instead, heterosexual or bisexual persons who either deliberately misrepresented their sexual orientation in order to appear more "typically" transsexual (Blanchard, 1985; Walworth, 1997) or who were pseudohomosexual, i.e., aroused by the autogynephilic fantasy of sex with a male partner but lacking a genuine erotic preference for the male somatotype (for a discussion, see Freund, 1985). Leavitt and Berger (1990), for example, reported that $36 \%$ of a group of $\mathrm{MtF}$ transsexuals who reported an erotic interest in male partners gave a history of sexual arousal with cross-dressing. However, $30 \%$ of participants had been married to women and $38 \%$ gave a history of sexual attraction to women, suggesting that many were bisexual, not homosexual. Similarly, Lawrence (2005), in a large survey of $\mathrm{MtF}$ transsexuals, found that most persons who reported sexual arousal to cross-dressing or cross-gender fantasy before SRS and who were characterized as homosexual based on their reported patterns of sexual partnering or attraction before SRS were arguably either bisexual (having been married to women or having had multiple female sexual partners before SRS) or asexual (having had no sexual partners before SRS).
}

pretending to be an amputee was associated with sexual arousal, but virtually all participants reported that their "preoccupation with becoming an amputee was first manifested by pretending" (p. 924), suggesting that pretending was not merely an incidental associated behavior. Given that the great majority of First's participants were sexually aroused by the idea of being an amputee, it is reasonable to assume that many found pretending, the first manifestation of their preoccupation, to be sexually arousing as well.

Another parallel between nonhomosexual MtF transsexualism and the desire for limb amputation is that persons with these conditions are usually sexually attracted to individuals with the same body type they want to acquire. By definition, this is not true of homosexual MtF transsexualism. Most nonhomosexual $\mathrm{MtF}$ transsexuals report a history of sexual attraction, exclusive or otherwise, to women, persons with the same body type they want to acquire. Blanchard (1985) noted that, in a group of 63 nonhomosexual $\mathrm{MtF}$ transsexuals, $81 \%$ reported that they were attracted to women or to both women and men; the remaining $19 \%$ were not sexually attracted to other persons of either sex. Lawrence (2005) found that, among $216 \mathrm{MtF}$ transsexuals who were not exclusively sexually attracted to men before SRS, $88 \%$ reported some sexual attraction to women before SRS (12\% were not sexually attracted to other persons of either sex) and $57 \%$ reported that they had been exclusively or almost exclusively attracted to women. In the study by First (2005), 87\% of persons who sought or achieved limb amputation reported that they were sexually attracted, exclusively or nonexclusively, to amputees, persons with the same body type they wanted to acquire.

Both nonhomosexual MtF transsexualism and desire for limb amputation also appear to be associated with an elevated prevalence of other paraphilic sexual interests. Little, if any, information exists concerning the prevalence of paraphilic sexual interests in homosexual MtF transsexuals. An elevated prevalence of other paraphilic interests is important heuristically because of the recognized tendency of paraphilias to co-occur or cluster (Abel \& Osborn, 1992; Bradford, Boulet, \& Pawlak, 1992). As previously noted, almost all nonhomosexual MtF transsexuals have a history of transvestic fetishism (Blanchard, 1985), a paraphilia (APA, 2000). Sadomasochistic fantasies and behaviors are also common in nonhomosexual MtF transsexuals. Bolin (1988) observed that, among a group of $12 \mathrm{MtF}$ transsexual informants, almost all of whom were nonhomosexual, 9 informants reported sadomasochistic fantasies and 8 had "actual experience with bondage and discipline" (p. 169). Similarly, Walworth (1997) reported that, among a group of $52 \mathrm{MtF}$ transsexual informants, $88 \%$ of whom appear to have been nonhomosexual, 5 (10\%) admitted to having lied 
to their therapists about their sadomasochistic practices or fantasies; she did not report how many informants had not lied about such practices or fantasies. Other paraphilias also occur in nonhomosexual $\mathrm{MtF}$ transsexuals, albeit less commonly. For example, Freund and Watson (1993) reported three instances of courtship disorders (voyeurism, exhibitionism, or toucheurism-frotteurism) in a group of 69 nonhomosexual $\mathrm{MtF}$ transsexuals. Other paraphilic interests were also common among First's (2005) survey participants: $29 \%$ had another non-amputationrelated paraphilia, including $15 \%$ with transvestic fetishism. Moreover, $87 \%$ reported sexual attraction to amputees (acrotomophilia), which is also regarded as a paraphilia (Dixon, 1983; Massie \& Szajnberg, 1997; Money, 1986).

A final parallel between nonhomosexual $\mathrm{MtF}$ transsexualism/GID and the desire for limb amputation is that many persons who experience these conditions feel that paraphilia-based explanations do not accurately or completely describe their experiences. This parallel does not apply to homosexual $\mathrm{MtF}$ transsexualism, which has not been proposed to be a paraphilia-related condition. Lawrence (2005) found that, among $199 \mathrm{MtF}$ transsexuals classified as nonhomosexual based on their sexual partnership pattern before SRS, 21 (11\%) did not report any history of sexual arousal to cross-dressing or cross-gender fantasy. Even nonhomosexual MtF transsexuals who acknowledge such a history often claim that sexual arousal was unrelated to their desire to change their bodies and live as women (for a discussion, see Lawrence, 2004). These MtF transsexuals insist that their desire is primarily related to expressing their true identities. Many persons who seek limb amputations report similar feelings. First (2005) distinguished between persons who said that sexual arousal was their primary motivation for seeking amputation and those who said that their primary motivation was achieving congruence between their bodies and identities. Only $15 \%$ of his participants said that sexual excitement was their primary reason for seeking amputation, versus $64 \%$ who said that expressing their "true identity" was primary and $21 \%$ who gave some other primary reason. Furth and Smith (2000) likewise acknowledged the existence of wannabes who sought limb amputation for sexual reasons, but contrasted them with wannabes for whom limb amputation was "not about sexual gratification, but ... about their identity" (p. 71).

\section{Erotic Target Location Errors and Amputation- Related Sexual Interests}

A recognized but underappreciated paraphilic category or dimension called erotic target location errors provides an explanation of transvestic fetishism and nonhomosexual MtF transsexualism/GID and may also have relevance for understanding the relationship between acrotomophilia, pretending, and apotemnophilia. Freund and Blanchard (1993) introduced the concept of erotic target location errors to explain why some men experience erotic fantasies of impersonating or changing their bodies to resemble the type of person for whom they experience sexual desire. They proposed that:

For every class of sexual object, there will be small subgroups of men who develop fetishes for clothing associated with the desired object, who develop the erotic fantasy of being the desired object, and who develop the sustained wish to transform their own bodies into facsimiles of the desired object. (p. 562)

Freund and Blanchard suggested that these men experienced erotic target location errors: Whatever their preferred erotic target, these individuals located that erotic target not only in other people, but also, and sometimes preferentially, in themselves.

For heterosexual men, the preferred erotic target is mature women, an erotic preference called gynephilia. According to the model proposed by Freund and Blanchard (1993), some heterosexual men who experience erotic target location errors for their preferred erotic target are also sexually aroused by wearing women's clothing or by otherwise temporarily attempting to resemble women; this manifests as the paraphilia called transvestic fetishism. Other heterosexual men who experience erotic target location errors for their preferred erotic target are sexually aroused by the idea of permanently changing their bodies to resemble women's bodies; this manifests as the paraphilia called autogynephilic transsexualism. The first row of Table II displays these relationships.

For homosexual men, the preferred erotic target is mature men, an erotic preference called androphilia. Some homosexual men who experience erotic target location errors for their preferred erotic target might be sexually aroused by wearing certain types of men's clothing; this phenomenon has been reported in homosexual men by Zavitzianos (1972, 1977), who called it homeovestism. He described, for example, the case of a man who masturbated to orgasm while wearing another man's military uniform and imagining that he was the other man (Zavitzianos, 1977). Other homosexual men who experience erotic target errors for their preferred erotic target might be sexually aroused by the idea of changing their bodies to resemble that erotic target, which would presumably be muscular, masculine-appearing men. Freund and Blanchard (1993) suggested that this type of erotic target location error, the 
Table II. Presentations of Uncomplicated Attraction and Erotic Target Location Errors in Men

\begin{tabular}{|c|c|c|c|}
\hline Erotic target & $\begin{array}{l}\text { Uncomplicated } \\
\text { attraction to target }\end{array}$ & $\begin{array}{l}\text { Desire to temporarily } \\
\text { resemble target }\end{array}$ & $\begin{array}{l}\text { Desire to transform one's body into } \\
\text { target or a facsimile of target }\end{array}$ \\
\hline Women & Gynephilia & Transvestism & Autogynephilic transsexualism \\
\hline Men & Androphilia & Homeovestism $^{\mathrm{b}}$ & Body-building in some gay men? ${ }^{\mathrm{c}}$ \\
\hline Children & Pedophilia & Pedovestism $^{\mathrm{d}}$ & Autopedophilia $^{\mathrm{d}}$ \\
\hline Amputees & Acrotomophilia & Pretending & Apotemnophilia \\
\hline
\end{tabular}

${ }^{\mathrm{a}}$ An erotic target location error.

${ }^{\mathrm{b}}$ Described by Zavitzianos $(1972,1977)$.

cDescribed as probably "subtle and difficult to detect" by Freund and Blanchard (1993, p. 562).

${ }^{\mathrm{d}}$ Described by Freund and Blanchard (1993), although they did not use this term.

homosexual equivalent of autogynephilic transsexualism, "would probably be subtle and difficult to detect" (p. 562). If such a phenomenon exists in homosexual men, it might plausibly take the form of body-building or other attempts to achieve a sexually appealing masculine somatotype. The second row of Table II displays these relationships.

Freund and Blanchard (1993) devoted most of their article to presenting case studies demonstrating the existence of analogues of transvestism and autogynephilia in pedophiles; they hypothesized that these analogues reflected erotic target location errors. They did not employ the terms pedovestism or autopedophilia, which appear in the third row of Table II, but these would be appropriate names for such analogues. Freund and Blanchard demonstrated that some pedophiles are sexually aroused by dressing in children's clothing and imagining that they are children. It is obviously difficult for an adult man to turn his body into a facsimile of a child's body, but Freund and Blanchard discussed one case in which a pedophilic patient sought reconstruction of his foreskin to approximate the appearance of a child who had not undergone circumcision; this plausibly may represent an instance of autopedophilia.

The concept of erotic target location errors can also be applied to amputation-related sexual interests, as shown in the fourth row of Table II. When a person's preferred erotic target is amputees, uncomplicated attraction to that erotic target is called acrotomophilia. Some acrotomophilic men who experience erotic target location errors for their preferred erotic target might be sexually aroused by temporarily presenting themselves as amputees; this would manifest as pretending. Other acrotomophilic men who experience erotic target locations errors for their preferred erotic target might be sexually aroused by the idea of changing their bodies to become amputees themselves; this would manifest as apotemnophilia.

This analysis suggests that apotemnophilia may represent the intersection of two distinctly different paraphilic aspects or dimensions. One dimension involves an uncommon erotic target preference: attraction to amputees, or acrotomophilia. The second dimension involves an erotic target location error, in which the individual desires to turn his body into the desired erotic target (or a facsimile thereof), rather than simply desiring that body configuration in another person. If apotemnophilia does represent the cooccurrence or intersection of an unusual erotic target preference and an erotic target location error, this may account for its relative rarity.

\section{Predictions from an Erotic-Target-Location-Error Model of Amputation-Related Interests}

A model that conceptualizes pretending and apotemnophilia as reflecting erotic target location errors when the preferred erotic target category is amputees generates some testable predictions. First of all, because this model understands pretending and apotemnophilia to be variant forms of acrotomophilia, it would predict that nearly all apotemnophiles would also be attracted to amputees (i.e., would also be acrotomophiles) and that most would also have engaged in pretending. The study by First (2005) of persons who desired or had undergone limb amputation $^{5}$ confirmed these predictions: $87 \%$ of participants reported that they were sexually attracted to amputees and $92 \%$ had engaged in pretending. Second, this model would predict that pretending and apotemnophilia would be less common than acrotomophilia. A brief perusal of Internet sites devoted to amputation-related sexual interests suggests that this is the case: A great many stories and photos of

${ }^{6}$ I will argue that the desire for limb amputation can be understood as a direct outgrowth of paraphilic sexual arousal/attraction to the idea of being an amputee and, consequently, that all or nearly all participants in the study by First (2005) can be understood as being apotemnophiles, whether or not they identified as such. However, even if one assumes that only a subset of First's participants were apotemnophiles, these data still confirm the predictions of the erotic-target-location-error model. 
amputees are available, but discussions of pretending to be or actually becoming an amputee are rare. The two large surveys conducted among devotees also confirmed this prediction: Roughly half of devotees did not report having engaged in pretending (Dixon, 1983; Nattress, 1996) and most devotees did not express a desire to actually become an amputee (Nattress, 1996).

A third prediction from the erotic-target-locationerror model follows from the additional observation that most devotees or acrotomophiles are men and that most of these men are sexually attracted to female amputees (Dixon, 1983; Furth \& Smith, 2000; Riddle, 1989). A man whose preferred erotic target was a female amputee and who experienced an erotic target location error for that erotic target might want to impersonate or become an amputee, might want to impersonate or become a female, or might want a combination of these things. Consequently, the erotictarget-location-error model would predict an increased prevalence of cross-dressing and gender identity problems in men with apotemnophilia. The study by First (2005) of persons who desired or had undergone limb amputation ${ }^{5}$ confirmed this prediction: Among his participants, $90 \%$ of whom were men, $29 \%$ reported a history of cross-dressing (about half of which was in connection with transvestic fetishism), 19\% reported feelings of wanting to be the opposite sex, $12 \%$ had considered undergoing sex reassignment, and one participant had actually done so. These percentages substantially exceed reported male prevalence rates of erotic cross-dressing (2.8\%; Langstrom \& Zucker, 2005) and gender dysphoria/transsexualism (0.013\%; Wilson, Sharp, \& Carr, 1999) and might have been even higher if First's participants had included fewer homosexual and bisexual men. It is also notable that, of six published case reports of pretending in men (Berger et al., 2005; Everaerd, 1983; London \& Caprio, 1950; Money \& Simcoe, 1986; Wakefield et al., 1977; Woody, 1973), three described individuals who also engaged in transvestism (London \& Caprio, 1950; Woody, 1973), two of whom either planned to undergo MtF SRS or had sexual fantasies about doing so. In another case report (Money \& Simcoe, 1986), the informant described an acquaintance who had undergone limb amputation and who engaged in transvestism. There are also published descriptions of $\mathrm{MtF}$ transsexuals who have undergone limb amputation (Berger et al., 2005, Ollason, 1996) or who wished to do so (Elliott, 2003)

\section{Objections to Conceptualizing the Desire for Limb Amputation as a Paraphilia}

Many persons who desire limb amputation and some clinicians familiar with the phenomenon reject the theory that the desire for amputation can beconceptualized as or reduced to a paraphilia (Body Integrity Identity Disorder, n.d.; First, 2005; Furth and Smith, 2000), although some concede that the desire for limb amputation may represent a paraphilia in some individuals. Consequently, I will briefly address a few criticisms of the theory that have been offered or that can be anticipated:

1. The age of onset of the desire for limb amputation is typically in early childhood, well before the onset of puberty; in the study by First (2005), about two thirds of participants recalled an onset of their desire prior to age 8 years. Prepubertal onset might imply that the desire for limb amputation is not primarily a sexual phenomenon.

2. If the desire for limb amputation represents an erotic target location error when the preferred erotic target category is amputees, one might expect that sexual attraction to amputees would be universal, or nearly so, among persons who desire amputation. In the study by First (2005), attraction to amputees was very common (87\%) but was not universal. This might imply that the desire for limb amputation sometimes might not arise from attraction to amputees.

3. A significant minority of persons who experience a desire for limb amputation deny any sexual arousal in association with their desire (First, 2005). This might imply that the desire for amputation is sometimes nonsexual and, therefore, nonparaphilic.

4. Persons who desire limb amputation do not comprise a homogeneous group. Perhaps some persons who desire limb amputation are indeed similar to nonhomosexual $\mathrm{MtF}$ transsexuals, in that their desire originates in paraphilic sexual arousal, but other persons who desire limb amputation are similar to homosexual $\mathrm{MtF}$ transsexuals, whose desires to change their bodies are unrelated to sexual arousal.

5. Most persons who desire limb amputation, even those who acknowledge some sexual motivation, report that achieving congruence between their bodies and their identities is a more important motivating factor than is sexuality. This might imply that paraphilic sexual arousal, even when present, cannot by itself explain the desire for amputation.

These criticisms can be addressed from the perspective of clinical experience and research concerning $\mathrm{MtF}$ transsexualism/GID. 


\section{Prepubertal Onset of Conditions Associated With Paraphilic Sexual Arousal}

In nonhomosexual $\mathrm{MtF}$ transsexuals who acknowledge substantial autogynephilic arousal, the age of onset of the desire to be the other sex is also typically prepubertal. In a survey of $\mathrm{MtF}$ transsexuals who had undergone SRS, Lawrence (2001) found that over two thirds of participants who reported having experienced hundreds of episodes or more of autogynephilic arousal before SRS recalled that they first experienced the wish to be of the other sex before age 8 years. Retrospective self-reports of this kind, whether by MtF transsexuals or by persons desiring limb amputation, are, of course, subject to biases and inaccuracies. If accurate, however, they suggest that a prepubertal age of onset does not necessarily imply that a condition is unrelated to sexuality or cannot represent a paraphilia. There have also been two case reports of physiologic sexual arousal (i.e., penile erection) associated with cross-dressing in boys younger than age 3 years (Zucker \& Blanchard, 1997; Stoller, 1985); it seems probable that these boys might eventually have met criteria for transvestic fetishism or autogynephilia. Case reports like these demonstrate that overtly sexual behavior that plausibly is an early manifestation of transvestic fetishism or autogynephilia can occur well before puberty.

\section{Self-Focused Sexuality in Persons with Erotic Target Location Errors}

If the desire for limb amputation is the result of an erotic target location error when the preferred erotic target category is amputees, why isn't sexual attraction to amputees universal (or nearly so) among persons who desire limb amputation? A similar situation has been observed in nonhomosexual transsexualism: Only about $81 \%$ (Blanchard, 1985) to 88\% (Lawrence, 2005) of nonhomosexual $\mathrm{MtF}$ transsexuals are sexually attracted to women; the rest are not sexually attracted to other persons of either sex. Blanchard (1992) observed that, in a group of nonhomosexual MtF transsexuals and transvestites, autogynephilia could compete with alloerotic (other-focused) gynephilia. In other words, some nonhomosexual MtF transsexuals may be so sexually interested in the fantasy or reality of themselves as women that they are relatively sexually disinterested in other women. Something similar may have been true of First's (2005) participants who reported no sexual interest in amputees: Some of them may have been so sexually interested in the fantasy or reality of themselves as amputees that they were relatively sexually disinterested in other amputees. There is no indication that First asked his participants whether or not they were sexually attracted to other people, but I speculate that most or all of those who were not sexually attracted to amputees probably were not sexually attracted to other people of any body type, but were instead primarily sexually attracted to the fantasy or reality of themselves as amputees.

\section{Accounting for Denial of Sexual Arousal in Putatively Paraphilic Conditions}

How can one explain why a significant minority of persons who desire limb amputation deny experiencing any sexual arousal in association with their desire, as reported by First (2005)? Similar statements have been made by some transvestites and nonhomosexual MtF transsexuals, who deny sexual arousal in association with cross-dressing or crossgender fantasy (e.g., Bentler, 1976; Buhrich, 1978; Buhrich \& McConaghy, 1978; Freund et al., 1982). There is evidence, however, that denial of sexual arousal with cross-dressing or cross-gender fantasy does not necessarily mean that no physiological arousal is occurring (Docter, 1988). As previously noted, Blanchard et al. (1986) demonstrated that, in a group of nonhomosexual $\mathrm{MtF}$ transsexuals and transvestites, persons who denied sexual arousal with cross-dressing nevertheless displayed significantly greater phallometrically-measured sexual arousal while listening to audio recordings of cross-dressing scenarios than while listening to neutral audiotapes. Persons who desire limb amputation and who deny sexual arousal in association with their desire may simply not be reporting accurately, as is evidently true of some nonhomosexual MtF transsexuals and transvestites.

In a study that may partly explain this phenomenon, Blanchard, Clemmensen, and Steiner (1985) observed that the tendency of nonhomosexual $\mathrm{MtF}$ transsexuals to deny sexual arousal with crossdressing was significantly correlated with their tendency to portray themselves in a socially desirable manner on the Crowne-Marlowe Social Desirability Scale. These results suggest that socially desirable responding may affect the accuracy of self-reported autogynephilic sexual arousal in nonhomosexual $\mathrm{MtF}$ transsexuals. Socially desirable responding may also provide an explanation for the denial of sexual arousal by some persons who desire amputation.

Socially desirable responding may take the form of either (a) impression management, i.e., deliberate misrepresentation, or (b) self-deceptive enhancement, i.e., positively biased self-presentation that is inaccurate but that a person honestly believes (Paulhus, 1984). Both forms. 
of socially desirable responding appear to contribute to denial of autogynephilic arousal by nonhomosexual $\mathrm{MtF}$ transsexuals and both may plausibly contribute to denial of sexual arousal by persons seeking limb amputation. Deliberate misrepresentation concerning paraphilic sexual arousal has been reported in nonhomosexual MtF transsexuals who wish to portray themselves as suitable candidates for surgical interventions. Walworth (1997), for example, noted that $13 \%$ of a group of 52 mostly-nonhomosexual MtF transsexual informants admitted that they had lied to their therapists by denying sexual arousal to crossdressing, "in order to increase their chances of obtaining approval for SRS" (p. 360). A similar phenomenon may have occurred among First's (2005) informants. Although First was not in a position to provide approval of amputations for these anonymous individuals, they may have believed that their answers could influence the future availability of amputations for themselves or for others with similar desires. Selfdeceptive enhancement may account for other instances in which nonhomosexual MtF transsexuals inaccurately deny sexual arousal to cross-dressing or cross-gender fantasy yet insist that they are reporting truthfully (e.g., Blanchard et al.,1986). Docter (1988) proposed that some $\mathrm{MtF}$ transgender persons may experience physiologic sexual arousal but may not consciously recognize it as such, either not noticing their arousal or interpreting it as something else, such as nonsexual excitement or pleasure. Similar selfdeceptive enhancement plausibly may occur in some persons who desire limb amputation and who deny sexual arousal in association with their desire.

Are Some Persons Who Desire Limb Amputation Similar to Homosexual MtF Transsexuals?

As previously noted, some persons who desire limb amputation report no sexual arousal in association with their desire. An alternative explanation of this phenomenon, one implicitly suggested by First (2005), argues that these individuals might be analogous to homosexual $\mathrm{MtF}$ transsexuals, who are not sexually aroused by cross-dressing or cross-gender fantasy (Whitam, 1987, 1997) and whose transsexualism is not hypothesized to originate in paraphilic arousal. Persons desiring limb amputation who do report associated sexual arousal would then be analogous to nonhomosexual MtF transsexuals. In First's study, $35 \%$ of participants reported that they experienced no sexual arousal to the idea of being an amputee and that identity was either their primary reason or an important secondary reason for wanting limb amputation; hypothetically, these individuals might be analogous to homosexual MtF transsexuals.

The most significant problem with this alternative explanation is that the analogy to homosexual $\mathrm{MtF}$ transsexualism does not hold up when one considers the crucial issue of the motivation for wanting to change one's body and status. Homosexual MtF transsexuals are not sexually aroused by the idea of being women, but instead seek sex reassignment because they are, as previously noted, naturally very feminine on many physical and behavioral dimensions (Blanchard et al., 1995; Whitam, 1987, 1997), resulting in the prospect of greater social and romantic satisfaction and success after sex reassignment than before. Natural resemblance to the status they want to attain (i.e., womanhood) thus provides an obvious explanation for homosexual MtF transsexuals' desire to undergo sex reassignment. No analogous phenomenon, however, has been observed in persons who desire limb amputation and who deny paraphilic arousal. As previously noted, these individuals do not naturally resemble, in any observable way, the status they want to attain (i.e., being an amputee). Absent such a natural resemblance, and with sexuality rejected as a motivation, this alternative explanation cannot explain the desire for limb amputation in persons who deny paraphilic arousal. Consequently, it must instead posit some unspecified "mismatch between their actual and perceived body schema" (Fisher \& Smith, 2000) or some inexplicable disturbance of "core body identity" (First, 2005, p. 927), neither of which has been demonstrated to exist in homosexual MtF transsexuals or to differentiate homosexual and nonhomosexual $\mathrm{MtF}$ transsexualism. Thus, concerning the crucial issue of motivation, the proposed analogy to homosexual $\mathrm{MtF}$ transsexualism offers no genuine explanatory value.

Moreover, this alternative explanation, with its proposed analogy to homosexual transsexualism, cannot explain why some persons who want to be amputees and who deny associated sexual arousal nevertheless report specific sexual attraction to other amputees. Homosexual MtF transsexuals are not sexually attracted to persons with the body type they want to acquire and, by analogy, one would expect that persons who want to be amputees but who deny associated sexual arousal would not be attracted to persons with the body type they want to acquire (i.e., amputees). But $35 \%$ of participants in the study by First (2005) denied sexual arousal, while only $13 \%$ were not attracted to amputees (and most of the latter plausibly represented apotemnophilic persons who were simply not sexually attracted to other people). Why did so many of First's ostensibly nonparaphilic participants express a particular sexual attraction to amputees? The explanation reported by First ("given that they felt more sexually comfortable being an amputee, they found themselves sexually attracted to other amputees as well"; p. 925) is 
implausible. Greater sexual comfort with oneself might promote freer expression of an existing sexual attraction, but it is not clear why it should generate a particular sexual attraction to the same category of persons one wants to resemble. Homosexual MtF transsexuals might plausibly feel more sexually comfortable after undergoing SRS, but this does not cause them to become sexually attracted to women.

\section{Attachment and Eroticism as Dimensions of Sexuality and Love}

Even if some nonhomosexual MtF transsexuals and persons who desire limb amputation are accurate in reporting that they do not experience sexual arousal to the idea of changing their bodies to match their desires, I will argue that it is still plausible to conceptualize their desires as arising from paraphilic sexual arousal, recognized or unrecognized. This is because, especially in men, sexual arousal can give rise to sustained attachment or bonding to the object or target of one's erotic interest, whether this is another person or is the image or reality of one's physically transformed self. I will further argue that this sustained attachment, which is arguably sexual but which may not be overtly erotic, can overshadow or outlast the paraphilic sexual desire that putatively inspired it.

It is widely recognized that the emotions and behaviors that underlie human mating, partnering, and reproduction (i.e., sexuality, broadly defined) involve a propensity for individuals to develop and maintain sustained associations with their partners or with the objects of their love or desire. This attachment-related dimension of human sexuality is sometimes referred to as romantic love (Hazan \& Shaver, 1987) or companionate love (Fisher, 2000; Fisher, Aron, Mashek, Li, \& Brown, 2002) and it is potentially independent of eroticism, sexual arousal, or lust (Diamond, 2003). Various models incorporating eroticism and attachment as distinct dimensions of human sexuality have been proposed. Fisher (2000; Fisher et al., 2002), for example, suggested that mammalian sexuality involves three interrelated but potentially independent emotional/motivational systems: a libidinal system ("lust"), which facilitates sexual interaction with any appropriate partner; an attraction system ("romantic love"), which focuses attention on a preferred sexual partner; and an attachment system ("companionate love"), which facilitates bonding and partnering (e.g., in mutual caregiving and performance of parental tasks). Shaver, Hazan, and Bradshaw (1988), in contrast, proposed that adult love (i.e., mating, partnering, and reproduction) involves three distinct but integrated biobehavioral systems: sexuality (i.e., desire, arousal, copulation, and orgasm), attachment ("romantic love"), and caregiving.
Diamond (2003) concluded that sexual desire and affectional bonding (attachment) were independent, albeit bidirectionally linked, components of human sexuality; she proposed that attraction (also called infatuation or limerence; Tennov, 1979) was simply an early-developing component of affectional bonding or attachment. Although Diamond argued that attachment could lead to sexual desire, especially in women, she observed that the reverse sequence was more typical, especially among men. Men typically develop romantic attractions or attachments to individuals (or objects) for whom they have first experienced sexual desire (see also Berscheid, 1988, and Dermer \& Pyszczynski, 1978).

Eroticism and attachment appear to operate as distinct but related dimensions of paraphilic sexuality as well as normophilic sexuality. Money (1986), for example, described paraphilic erotic-romantic orientations ${ }^{6}$, like normophilic sexual orientations, as being defined by lovemaps and he emphasized that the paraphilias involve affectional bonding and attachment as well as sexual desire: "It is not fully correct to designate the paraphilias as sexual disorders. More accurately they are disorders of love and lovebonding." (p. 32). Similarly, Blanchard (1991) argued that men who experienced sexual arousal to the idea of having a woman's body might also experience attachment to the image of themselves as women, the object of their erotic interest. In nonhomosexual $\mathrm{MtF}$ transsexuals, he proposed, the desire to preserve and strengthen one's attachment or bond to the image of one's feminized self could lead to a desire for SRS, thus making the bond to one's self-image as a woman more real and permanent:

[Autogynephilic transsexuals] are most aroused sexually by the idea of having a woman's body, and they are most interested in acquiring a woman's body. Viewed in this light, the[ir] desire for sex reassignment surgery . . . appears as logical as the desire of heterosexual men to marry wives, the desire of homosexual men to establish permanent relationships with male partners, and perhaps the desire of other paraphilic men to bond with their paraphilic objects in ways no one has thought to observe. (pp. 245-246)

\footnotetext{
${ }^{7}$ I would prefer to use the term sexual orientation in reference to paraphilic sexual interests, but that term typically is used only to denote a tendency to choose sexual and romantic partners of the other sex, the same sex, or both sexes. Consequently, I will use the term erotic-romantic orientation to denote the tendency to be erotically attracted to, and to fall in love with, any of a broader range of erotic targets.
} 


\section{Conceptualizing Sexual Attachment to Oneself or to Aspects of Oneself}

The idea of sexual attachment to oneself, or to an aspect or image of oneself, is easier to understand if individuals' self-representations are thought of as multifaceted or as consisting of multiple coexisting selves. Clinical accounts of nonhomosexual $\mathrm{MtF}$ transsexualism and male transvestism often employ descriptions of this kind, which, in turn, reflect patients' self-descriptions. For example, Hirschfeld (1910/1991), discussing transvestites and persons who would now be considered nonhomosexual $\mathrm{MtF}$ transsexuals, wrote:

A division of the personality enters here in such a manner that the masculine part in the psyche of these people is sexually excited by their feminine side, that they feel attracted not only by women outside themselves, but also more so by the women within themselves. (p. 140)

Buckner (1970) described a similar phenomenon occurring in transvestites:

Elaboration of masturbation fantasies into a feminine self ... [is] gratifying in both sexual and social ways. When it becomes fixed in his identity, he begins to relate toward himself in some particulars as if he were his own wife. . . His internal relationship may then be so strong that he will maintain it . . . and it will continue as his pattern of gratification, and his pattern of social relationship, for the rest of his life. (pp. 384, 387)

Ovesey and Person (1976) likewise described transvestites as experiencing distinct male and female personalities or male and female aspects their personalities. Doctor (1988) similarly explained the progression from transvestism to nonhomosexual MtF transsexualism as resulting from a competition between coexisting self-systems within an individual.

I hypothesize that this explanation may also be relevant to persons whose erotic-romantic orientations or lovemaps are characterized by sexual arousal, recognized or unrecognized, to the idea of being an amputee. In addition to arousal, these individuals probably also experience affectional bonding and attachment to the object of their putative erotic interest, i.e., the image, fantasy, or reality of themselves as amputees.

\section{Sexual Attachment Can Outlast or Overshadow Sexual Desire}

Although feelings of sexual desire and attachment frequently coexist, it is widely recognized that attachment can occur independently of sexual desire and can outlast or overshadow it (Diamond, 2003;
Fisher, 2000; Fisher et al., 2002). This results in the possibility of sustained attachment or affectional bonding to an individual or paraphilic object that may no longer have much erotic or lusty valence. Blanchard (1991) described this phenomenon in nonhomosexual MtF transsexuals:

In later years, however, autogynephilic sexual arousal may diminish or disappear, while the transsexual wish remains or grows even stronger. . . . It is therefore feasible that the continuing desire to have a female body, after the disappearance of sexual response to that thought, has some analog in the permanent love-bond that may remain between two people after their initial strong sexual attraction has largely disappeared. (p. 248)

Thus, nonhomosexual MtF transsexuals who report that their motives for wanting to become women are unrelated to feelings of sexual arousal might still experience feelings of attachment to the image or reality of their feminized selves and these feelings might plausibly contribute to the ostensibly "nonsexual" motivations they report. I hypothesize, however, that these feelings probably originated in autogynephilic arousal. Something similar may be true of persons who seek limb amputation. Although sexual arousal to the idea of being an amputee may not be a primary motive and may not even be consciously experienced, feelings of attachment to the image of themselves as amputees, plausibly arising from earlier sexual arousal, might contribute substantially to the ostensibly "nonsexual" motivations these individuals report.

\section{Sexual Orientation, Paraphilia, and Identity}

Perhaps the most serious objection to the idea that the desire for limb amputation can be conceptualized as a paraphilia is that many people with this desire, including some who acknowledge a history of sexual arousal in association with it, insist that issues of identity are more central to their motivation than are issues of sexuality. I will argue, however, that an individual's sexuality (i.e., erotic-romantic orientation) and identity are often so intertwined that distinctions between "sexually-based motivations" and "identitybased motivations" are not likely to be meaningful or useful. This is especially true in the context of erotic target location errors, which can be expected to profoundly influence identity.

In modern Western culture, sexual orientation contributes significantly to the creation and maintenance of personal identity in most persons with normophilic sexual orientations (Katz, 1995; Levine, Risen, \& Althof, 1990; Person, 1980). A similar process plausibly occurs in persons with atypical erotic-romantic orientations. 
Consequently, distinctions between "sexual motivations" and "identity motivations" for seeking sex reassignment or limb amputation may not be meaningful or useful.

As Katz (1995) noted, "We are all now socially pressured to privately believe in and publicly proclaim our 'sexual identities' as the defining truth of who we are" (p. 171). The effectiveness of this social paradigm is illustrated by statistics from the National Health and Social Life Survey (Laumann, Gagnon, Michael, \& Michaels, 1994), in which $99.7 \%$ of men and $99.9 \%$ of women could report a heterosexual, bisexual, or homosexual identity. These figures suggest that the concept of an identity grounded, at least in part, in sexual orientation or sexual preference is meaningful to the vast majority of contemporary Americans.

Sexuality appears to function as a central element of identity in paraphilic erotic-romantic orientations, just as it does in normophilic sexual orientations (Levine et al., 1990). Person (1980) suggested that an individual's unique erotic-romantic orientation or sex print (similar to Money's lovemap) can be an especially important source of identity in the case of "deviant" sexual preferences or paraphilic eroticromantic orientations:

Because it is revealed rather than chosen, sexual preference is felt as deeply rooted and deriving from one's nature. To the degree that one utilizes sexuality (for pleasure, for adaptation, as the resolution of unconscious conflict) and to the degree that sexuality is valued, one's sexual "nature" will be experienced as more or less central to personality. To the extent that an individual's sex print "deviates" from the culture's prescription for sexuality, it may be experienced as even more central to identity (at least in this culture). So, for example, many transsexuals and transvestites report both relief and a sense of personality consolidation when "I found out what I am," when "I found out there were others like me." (p. 51)

Moreover, it would seem self-evident that paraphilic erotic-romantic orientations involving erotic target location errors would make especially potent contributions to identity, because, by definition, they involve feelings about the self, about who or what one wants to resemble or what one wants to turn one's body into. In the case of nonhomosexual $\mathrm{MtF}$ transsexuals, the sexual desire to turn one's body into a facsimile of a woman's body and the resulting attachment to this self-image might eventually lead to the feeling that one's true identity is "woman." It seems plausible that this life-defining sense of identity could come to feel large in relation to the sexual feelings from which it hypothetically originated, particularly if the erotic or lusty dimension of those feelings had diminished with time. This perspective makes it easier to understand the reports of nonhomosexual MtF transsexuals who insist that they experience their feelings as being, or as having become, primarily about "identity" rather than about "sexuality" (i.e., the erotic or lusty component of sexuality).

In the case of persons who desire limb amputation, the sexual desire to turn one's body into the body form of an amputee and the resulting attachment to this self-image might similarly lead to the feeling that one's true identity is "amputee." It seems equally plausible that this "amputee identity" could be experienced as overshadowing the sexual feeling from which it hypothetically originated, especially if the erotic or lusty components of those sexual feelings had become weaker with time.

\section{Research and Treatment Implications}

Experience with nonhomosexual $\mathrm{MtF}$ transsexualism/GID suggests possible directions for research and treatment for persons who desire limb amputation. One possible area of research would involve attempts to better understand the reports by some persons who desire limb amputation that they experience no sexual arousal in association with their desire. As previously noted, Blanchard et al. (1985) demonstrated that denial of sexual arousal to crossdressing by nonhomosexual gender dysphoric men was correlated with socially desirable self-description on the Crowne-Marlowe Social Desirability Scale. I hypothesize that similar results might be found in persons who desire limb amputation and who deny sexual arousal in association with their desire. Blanchard et al. (1986) also demonstrated that transvestites and nonhomosexual MtF transsexuals who denied sexual arousal to cross-dressing nevertheless displayed greater phallometrically-measured sexual arousal to audiotapes describing cross-dressing scenarios than to neutral audiotapes. Conducting a similar investigation using audiotaped descriptions of amputation-related scenarios in men who desire limb amputation and who deny associated sexual arousal might shed further light on these self-reports.

Experience with nonhomosexual $\mathrm{MtF}$ transsexualism/GID also suggests possible directions for treatment. Testosterone-lowering medications (e.g., antiandrogens such as cyproterone acetate and gonadotropin hormone-releasing hormone agonists such as triptorelin) have proven useful in managing the symptoms of some paraphilias (Bradford, 2000; Gijs \& Gooren, 1996). In nonhomosexual male gender patients, unwanted feelings of sexual arousal associated with cross-gender expression have been found to be positively correlated with feelings of gender dysphoria (Blanchard \& Clemmensen, 1888). Lawrence (2004) proposed that part of the effectiveness 
of feminizing hormone therapy in nonhomosexual MtF transsexuals might be related to its testosteronelowering effects, leading to reduction of ego-dystonic autogynephilic sexual arousal. If the desire for limb amputation in men is genuinely a paraphilic phenomenon, then treatment with testosteronelowering medications might sometimes offer symptomatic relief, especially if associated feelings of sexual arousal were prominent and unwanted.

Finally, and perhaps most controversially, experience with nonhomosexual MtF transsexualism/GID suggests that surgery can sometimes be an effective solution for persons who experience an unwavering desire to transform their bodies, even when that desire can be understood as a direct outgrowth of paraphilic sexuality. MtF transsexuals of whatever type who undergo SRS are usually very satisfied with their decisions (Green \& Fleming, 1990; Lawrence, 2003; Muirhead-Allwood, Royle, \& Young, 1999) and rarely express regrets about SRS per se, although a few express regrets related to other aspects of the reassignment process (Lawrence, 2003). Some studies (e.g., Blanchard, Steiner, Clemmensen, \& Dickey, 1989; Smith, van Goozen, Kuiper, \& Cohen-Kettenis, 2005) have suggested that regret after MtF SRS may be more likely in nonhomosexual MtF transsexuals than in their homosexual counterparts. However, neither the presence nor the frequency of autogynephilic arousal before MtF SRS was found to be associated with regret or dissatisfaction after SRS in one study that specifically examined these participant characteristics (Lawrence, 2003). In MtF transsexualism, surgical treatment of persons who experience erotic target locations errors can apparently result in high levels of satisfaction and minimal regret. This may also be true in persons who desire limb amputation, as the limited data concerning persons who have undergone such amputations (First, 2005) appear to suggest.

\section{ACKNOWLEDGMENT}

The author thanks Paul L. Vasey for reviewing an earlier version of the manuscript.

\section{REFERENCES}

Abel, G. G., \& Osborn, C. (1992). The paraphilias. The extent and nature of sexually deviant and criminal behavior. Psychiatric Clinics of North America, 15, 675-687.

American Psychiatric Association. (1987). Diagnostic and statistical manual of mental disorders (3rd ed., revised). Washington, DC: Author.

American Psychiatric Association. (2000). Diagnostic and statistical manual of mental disorders (4th ed., text revision). Washington, DC: Author.

BBC2 Horizon (Producer). (2000, February 17). Complete obsession [Television broadcast]. London: BBC. Tran- script retrieved January 3, 2005, from http:// www.bbc. co.uk/science/horizon/1999/obsession_script.shtml

Bensler, J. M., \& Paauw, D. S. (2003). Apotemnophilia masquerading as medical morbidity. Southern Medical Journal, 96, 674-676.

Bentler, P. M. (1976). A typology of transsexualism: Gender identity theory and data. Archives of Sexual Behavior, $5,567-584$.

Berger, B. D., Lehrmann, J. A., Larson, G., Alverno, L., \& Tsao, C. I. (2005). Nonpsychotic, nonparaphilic selfamputation and the internet. Comprehensive Psychiatry, 46, 380-383.

Berscheid, E. (1988). Some comments on love's anatomy: Or, what ever happened to old fashioned lust? In R. J. Sternberg \& M. L. Barnes (Eds.), The psychology of love (pp. 359-374). New Haven, CT: Yale University Press.

Blanchard, R. (1985). Typology of male-to-female transsexualism. Archives of Sexual Behavior, 14, 247-261.

Blanchard, R. (1988). Nonhomosexual gender dysphoria. Journal of Sex Research, 24, 188-193.

Blanchard, R. (1989a). The classification and labeling of nonhomosexual gender dysphorias. Archives of Sexual Behavior, 18, 315-334.

Blanchard, R. (1989b). The concept of autogynephilia and the typology of male gender dysphoria. Journal of Nervous and Mental Disease, 177, 616-623.

Blanchard, R. (1990). Gender identity disorders in adult men. In R. Blanchard \& B. Steiner (Eds.), Clinical management of gender identity disorders in children and adults (pp. 49-76). Washington, DC: American Psychiatric Press.

Blanchard, R. (1991). Clinical observations and systematic studies of autogynephilia. Journal of Sex and Marital Therapy, 17, 235-251.

Blanchard, R. (1992). Nonmonotonic relation of autogynephilia and heterosexual attraction. Journal of Abnormal Psychology, 101, 271-276.

Blanchard, R., \& Clemmensen, L. H. (1988). A test of the DSM-III-R's implicit assumption that fetishistic arousal and gender dysphoria are mutually exclusive. Journal of Sex Research, 25, 426-432.

Blanchard, R., Clemmensen, L. H., \& Steiner, B. W. (1985). Social desirability response set and systematic distortion in the self-report of adult male gender patients. Archives of Sexual Behavior, 14, 505-516.

Blanchard, R., Clemmensen, L. H., \& Steiner, B. W. (1987). Heterosexual and homosexual gender dysphoria. Archives of Sexual Behavior, 16, 139-152.

Blanchard, R., Dickey, R., \& Jones, C. L. (1995). Comparison of height and weight in homosexual versus nonhomosexual male gender dysphorics. Archives of Sexual Behavior, 24, 543-554.

Blanchard, R., Racansky, I. G., \& Steiner, B. W. (1986). Phallometric detection of fetishistic arousal in heterosexual male cross-dressers. Journal of Sex Research, 22, 452-462.

Blanchard, R., Steiner, B. W., Clemmensen, L., \& Dickey, R. (1989). Prediction of regrets in postoperative transsexuals. Canadian Journal of Psychiatry, 34, 43-45.

Body integrity identity disorder (n.d.). Retrieved January 3, 2005, from http://www.biid.org 
Bolin, A. (1988). In search of Eve: Transsexual rites of passage. New York: Bergin \& Garvey.

Bradford, J. M. W. (2000). The treatment of sexual deviation using a pharmacological approach. Journal of Sex Research, 37, 248-257.

Bradford, J. M., Boulet, J., \& Pawlak, A. (1992). The paraphilias: A multiplicity of deviant behaviours. Canadian Journal of Psychiatry, 37, 104-108.

Bruno, R. L. (1997). Devotees, pretenders, and wannabes: Two cases of factitious disability disorder. Sexuality and Disability, 15, 243-260.

Buckner, H. T. (1970). The transvestic career path. Psychiatry, 33, 381-389.

Buhrich, N. (1978). Motivations for cross-dressing in heterosexual transvestism. Acta Psychiatrica Scandinavica, 57, 145-152.

Buhrich, N., \& McConaghy, N. (1978). Two clinically discrete syndromes of transsexualism. British Journal of Psychiatry, 133, 73-76.

Cohen-Kettenis, P. T., \& Gooren, L. J. G. (1999). Transsexualism: A review of etiology, diagnosis and treatment. Journal of Psychosomatic Research, 46, 315-333.

Dermer, M., \& Pyszczynski, T. A. (1978). Effects of erotica upon men's loving and liking responses for women they love. Journal of Personality and Social Psychology, 36, 1302-1309.

Diamond, L. M. (2003). What does sexual orientation orient? A biobehavioral model distinguishing romantic love and sexual desire. Psychological Review, 110, 173-192.

Dixon, D. (1983). An erotic attraction to amputees. Sexuality and Disability, 6, 3-19.

Docter, R. F. (1988). Transvestites and transsexuals: Toward a theory of cross-gender behavior. New York: Plenum.

Doorn, C. D., Poortinga, J., \& Verschoor, A. M. (1994). Cross-gender identity in transvestites and male transsexuals. Archives of Sexual Behavior, 23, 185-201.

Dotinga, R. (2000, August 29). Out on a limb. Salon. Retrieved January 3, 2005, from http://dir.salon.com/ health/feature/2000/08/29/amputation/index.html

Duncan, K. (Producer). (2002, April 12). Wannabes [Radio broadcast]. Laurel, MD: Soundprint. Retrieved January 3, 2005, from http://www.soundprint.org/ radio/ display_show/ID/87/name/Wannabes

Dyer, C. (2000). Surgeon amputated healthy legs. BMJ, 320, 332.

Elliott, C. (2000, December) A new way to be mad. Atlantic Monthly, 286, 72-84.

Elliott, C. (2003). Amputees by choice. In Better than well: American medicine meets the American dream (pp. 208-236). New York: Norton.

Ellis, H. (1936). Studies in the psychology of sex (Vol. 2). New York: Random House.

Everaerd, W. (1983). A case of apotemnophilia: A handicap as sexual preference. American Journal of Psychotherapy, 37, 285-293.

First, M. B. (2005). Desire for amputation of a limb: Paraphilia, psychosis, or a new type of identity disorder. Psychological Medicine, 35, 919-928.

Fisher, H. E. (2000). Lust, attraction, and attachment. Journal of Sex Education and Therapy, 25, 96-104.

Fisher, H. E., Aron, A., Mashek, D., Li, H., \& Brown, L. L. (2002). Defining the brain systems of lust, romantic attraction, and attachment. Archives of Sexual Behavior, 31, 413-419.

Fisher, K., \& Smith, R. (2000). More work is needed to explain why patients ask for amputation of healthy limbs [Letter to the editor]. BMJ, 320, 1147.

Freund, K. (1985). Cross gender identity in a broader context. In B. Steiner (Ed.), Gender dysphoria: Development, research, management (pp. 259-324). New York: Plenum.

Freund, K., \& Blanchard, R. (1993). Erotic target location errors in male gender dysphorics, paedophiles, and fetishists. British Journal of Psychiatry, 162, 558-563.

Freund, K., Steiner, B. W., \& Chan, S. (1982). Two types of cross-gender identity. Archives of Sexual Behavior, 11, 47-63.

Freund, K., \& Watson, R. J. (1993). Gender identity disorder and courtship disorder. Archives of Sexual Behavior, $22,13-21$.

Furth, G. M., \& Smith, R. (2000). Amputee identity disorder: Information, questions, answers, and recommendations about self-demand amputation. Bloomington, IN: 1 stBooks.

Gijs, L., \& Gooren, L. (1996). Hormonal and psychopharmacological interventions in the treatment of paraphilias: An update. Journal of Sex Research, 33, 273-290.

Gilbert, M. (Producer/Director). (2003). Whole [Motion picture]. (Available from M. Gilbert, 1794 Sargent Ave., St. Paul, MN 55105).

Green, R., \& Fleming, D. T. (1990). Transsexual surgery follow-up: Status in the 1990s. Annual Review of Sex Research, 1, 163-174.

Hazan, C., \& Shaver, P. (1987). Romantic love conceptualized as an attachment process. Journal of Personality and Social Psychology, 52, 511-524.

Hirschfeld, M. (1991). Transvestites: The erotic drive to cross-dress (M. A. Lombardi-Nash, Trans.). Buffalo, NY: Prometheus Books. (Original work published 1910)

Horn, F. (2003, February 24). A life for a limb: Body integrity identity disorder. Social Work Today, 3, 16-19.

Johnston, J., \& Elliott, C. (2002). Healthy limb amputation: Ethical and legal aspects. Clinical Medicine, 2, 431435.

Katz, J. N. (1995). The invention of heterosexuality. New York: Dutton.

Krafft-Ebing, R. (1965). Psychopathia sexualis (F. S. Klaf, Trans.). New York: Stein and Day. (Original work published 1903).

Laumann, E. O., Gagnon, J. H., Michael, R. T., \& Michaels, S. (1994). The social organization of sexuality: Sexual practices in the United States. Chicago: University of Chicago Press.

Langstrom, N., \& Zucker, K. J. (2005). Transvestic fetishism in the general population: Prevalence and correlates. Journal of Sex and Marital Therapy, 31, 87-95.

Lawrence, A. A. (2001). [Survey responses of transsexuals following vaginoplasty]. Unpublished raw data.

Lawrence, A. A. (2003). Factors associated with satisfaction or regret following male-to-female sex reassignment surgery. Archives of Sexual Behavior, 32, 299-315.

Lawrence, A. A. (2004). Autogynephilia: A paraphilic model of gender identity disorder. Journal of Gay \& Lesbian Psychotherapy, 8(1/2), 69-87. 
Lawrence, A. A. (2005). Sexuality before and after male-tofemale sex reassignment surgery. Archives of Sexual Behavior, 34, 147-166.

Leavitt, F., \& Berger, J. C. (1990). Clinical patterns among male transsexual candidates with erotic interest in males. Archives of Sexual Behavior, 19, 491-505.

Levine, S. B., Risen, C. B., \& Althof, S. E. (1990). Essay on the diagnosis and nature of paraphilia. Journal of Sex and Marital Therapy, 16, 89-102.

London, L. S., \& Caprio, F. S. (1950). Sexual deviations. Washington, DC: Linacre Press.

Massie, H., \& Szajnberg, N. (1997). The ontogeny of a sexual fetish from birth to age 30 and memory processes. A research case report from a prospective longitudinal study. International Journal of Psychoanalysis, 78, 755-771.

Meyer, W., III, Bockting, W. O., Cohen-Kettenis, P., Coleman, E., DiCeglie, D., Devor H., et al. (2001). The standards of care for gender identity disorders, sixth version. Düsseldorf: Symposion.

Money, J. (1986). Lovemaps: Clinical concepts of sexualerotic health and pathology, paraphilia, and gender transposition in childhood, adolescence, and maturity. New York: Irvington.

Money, J. (1990). Paraphilia in females: Fixation on amputation and lameness; two personal accounts. Journal of Psychology \& Human Sexuality, 3(2), 165-172.

Money, J., \& Gaskin, R. J. (1970-1971) Sex reassignment. International Journal of Psychiatry, 9, 249-269.

Money, J., Jobaris, R., \& Furth, G. (1977). Apotemnophilia: Two cases of self-demand amputation as a paraphilia. Journal of Sex Research, 13, 115-125.

Money, J., \& Simcoe, K. W. (1986). Acrotomophilia, sex, and disability: New concepts and case report. Sexuality and Disability, 7, 43-50.

Muirhead-Allwood, S. K., Royle, M. G., \& Young, R. (1999, August). Sexuality and satisfaction with surgical re-sults in male-to-female transsexuals. Poster session presented at the Harry Benjamin International Gender Dysphoria Association XVI Biennial Symposium, London.

Nattress, L. W., Jr. (1996). Amelotasis. Men attracted to women who are amputees: A descriptive study. Dissertation Abstracts International, 57(11-B), 7264. (UMI No. 9713650).

Ollason, J. G. (1996.). Denise Anne: An interview with the ultimate wannabee. Overground, 6, 20-35. Electronic version retrieved January 3, 2005, from http://www. overground.be/article.php?code $=36 \& l a n=e n$

Ovesey, L., \& Person, E. S. (1976). Transvestism: A disorder of the sense of self. International Journal of Psychoanalytic Psychotherapy, 5, 219-236.

Paulhus, D. L. (1984). Two-component models of socially desirable responding. Journal of Personality and Social Psychology, 46, 598-609.

Person, E. S. (1980). Sexuality as the mainstay of identity: Psychoanalytic perspectives. In C. R. Stimpson \& E. S. Person (Eds.), Women: Sex and sexuality (pp. 36-61). Chicago: University of Chicago Press.

Prosser, J. (1998). Second skins: The body narratives of transsexuality. New York: Columbia University Press.
Riddle, G. C. (1989). Amputees \& devotees. New York: Irvington.

Shaver, P., Hazan, C., \& Bradshaw, D. (1988). Love as attachment: The integration of three behavioral systems. In R. J. Sternberg \& M. L. Barnes (Eds.), The psychology of love (pp. 68-99). New Haven, CT: Yale University Press.

Smith, R. (2003, June). Amputee identity disorder: Is surgery appropriate? Paper presented at the Third International BIID Meeting, New York City.

Smith, Y. L. S., van Goozen, S. H. M., Kuiper, A. J., \& Cohen-Kettenis, P. T. (2005). Sex reassignment: Outcomes and predictors of treatment for adolescent and adult transsexuals. Psychological Medicine, 35, 89-99.

Stoller, R. J. (1985). A child fetishist. In Presentations of gender (pp. 93-136). New Haven, CT: Yale University Press.

Storm, S., \& Weiss, M. D. (2003). Self-inflicted tourniquet paralysis mimicking acute demyelinating polyneuropathy. Muscle \& Nerve, 27, 631-635.

Tennov, D. (1979). Love and limerence: The experience of being in love. New York: Stein \& Day.

Wakefield, P. L., Frank, A., \& Meyers, R. W. (1977). The hobbyist: A euphemism for self-mutilation and fetishism. Bulletin of the Menninger Clinic, 41, 539-552.

Walworth, J. R. (1997). Sex-reassignment surgery in male-tofemale transsexuals: Client satisfaction in relation to selection criteria. In B. Bullough, V. L. Bullough, \& J. Elias (Eds.), Gender blending (pp. 352-369). Amherst, NY: Prometheus Books.

Whitam, F. L. (1987). A cross-cultural perspective on homosexuality, transvestism, and trans-sexualism. In G. D. Wilson (Ed.), Variant sexuality: Research and theory (pp. 176-201). Baltimore, MD: Johns Hopkins University Press.

Whitam, F. L. (1997). Culturally universal aspects of male homosexual transvestites and transsexuals. In B. Bullough, V. L. Bullough, \& J. Elias (Eds.), Gender blending (pp. 189-203). Amherst, NY: Prometheus Books.

Wilson, P., Sharp, C., \& Carr, S. (1999). The prevalence of gender dysphoria in Scotland: A primary care study. British Journal of General Practice, 49, 991-992.

Wise, T. N., \& Kalyanam, R. C. (2000) Amputee fetishism and genital mutilation: Case report and literature review. Journal of Sex and Marital Therapy, 26, 339344.

World Health Organization. (1992). International statistical classification of diseases and related health problems (10th revision, Vol. 1). Geneva, Switzerland: Author.

Woody, R. H. (1973). Integrated aversion therapy and psychotherapy: Two sexual deviation case studies. Journal of Sex Research, 9, 313-324.

Zavitzianos, G. (1972). Homeovestism: Perverse form of behaviour involving wearing clothes of the same sex. International Journal of Psycho-analysis, 53, 471-477.

Zavitzianos, G. (1977). The object in fetishism, homeovestism and transvestism. International Journal of Psycho-analysis, 58, 487-495.

Zucker, K. J., \& Blanchard, R. (1997). Transvestic fetishism: Psychopathology and theory. In D. R. Laws \& W. O'Donohue (Eds.), Sexual deviance (pp. 253-279). New York: Plenum. 